\title{
Microwave Assisted Reactions of Fluorescent Pyrrolodiazine Building Blocks
}

\author{
Costel Moldoveanu ${ }^{1, *} \mathbb{C}$, Dorina Amariucai-Mantu ${ }^{1}$, Violeta Mangalagiu ${ }^{2}{ }^{\circ}$, Vasilichia Antoci ${ }^{1}$, \\ Dan Maftei ${ }^{1}\left(\mathbb{D}\right.$, Ionel I. Mangalagiu ${ }^{1}\left(\mathbb{D}\right.$ and Gheorghita Zbancioc ${ }^{1, *(1)}$ \\ 1 Chemistry Department, Alexandru Ioan Cuza University of Iasi, 11 Carol 1st Bvd, 700506 Iasi, Romania; \\ dorina.mantu@uaic.ro (D.A.-M.); vasilichia.antoci@uaic.ro (V.A.); dan.maftei@chem.uaic.ro (D.M.); \\ ionelm@uaic.ro (I.I.M.) \\ 2 Institute of Interdisciplinary Research CERNESIM Centre, Alexandru Ioan Cuza University of Iasi, 11 Carol I, \\ 700506 Iasi, Romania; violeta.mangalagiu@uaic.ro \\ * Correspondence: costel.moldoveanu@uaic.ro (C.M.); gheorghita.zbancioc@uaic.ro (G.Z.); \\ Tel.: +40-232-201278 (G.Z.)
}

Academic Editors: Maged Henary and Julio A.A. Seijas Vázquez

Received: 12 September 2019; Accepted: 16 October 2019; Published: 18 October 2019

check for updates

\begin{abstract}
We report here the synthesis and optical spectral properties of several new pyrrolodiazine derivatives. The luminescent heterocycles were synthesized by 1,3-dipolar cycloaddition reactions between $\mathrm{N}$-alkylated pyridazine and methylpropiolate or dimethyl acetylenedicarboxylate (DMAD). The pyrrolopyridazine derivatives are blue emitters with moderate quantum yields (around 25\%) in the case of pyrrolopyridazines and negligible yet measurable emission for pyrrolophthalazines. In a subsequent step towards including the pyrrolodiazine moiety, given its spectral properties in various macromolecular frameworks such as biological molecules, a subset of the synthetized compounds has been subjected to $\alpha$-bromination. A selective and efficient way for $\alpha$-bromination in heterogeneous catalysis of pyrrolodiazine derivatives under microwave (MW) irradiation is presented. We report substantially higher yields under MW irradiation, whereas the solvent amounts required are at least five-fold less compared to classical heating.
\end{abstract}

Keywords: pyrrolopyridazine; pyrrolophthalazine; microwave irradiation; fluorescent

\section{Introduction}

Pyrrolodiazines are an important class of N-bridgehead heterocycles which have received increasing interest during the last few years driven by a wide range of potential applications, from electroluminescent materials [1] to interesting biological uses [2]. In recent years, azaheterocycle derivatives have been reported to display a large variety of applications in the fields of medicinal chemistry (these include antimicrobials, anti-cancer, antioxidant, anti-human immunodeficiency virus (HIV), etc.) [2-8]. The interest in the field of pyrrolodiazine derivatives arises also from their highly efficient blue fluorescence emission [9-11]. The latter property makes pyrrolodiazine derivatives very attractive materials in optoelectronics for blue organic light-emitting diodes [9-11], whereas a combined use of the two distinct properties has suggested interesting applications as fluorescent biomarkers [12-14].

Pyrrolodiazines offer very interesting optical properties. Azaindolizines derivatives represent such a class (with $10 \pi$-electron $\mathrm{N}$-fused heterocycles, containing a bridgehead nitrogen atom shared by an electron-excessive pyrrole and a diazine electron deficient six-membered ring) being a 'pure' blue-emitting moiety. $[15,16]$. This uneven $\pi$-electron distribution between the two fused rings is an important feature that leads to electron delocalization. The electron delocalization within the entire heterocycle skeleton can be possible without a planar geometry of the indolizine. The planarity of 
azaindolizine is provided by the $\mathrm{sp}^{2}$ hybridization of all the atoms in the fused ring and is preserved upon substitution with different groups.

As a relatively new trend in synthetic organic chemistry, microwave (MW)-assisted reactions offer a versatile and facile pathway for an increasing number of organic syntheses $[17,18]$. In this respect, our group has presented (in previous work) several studies on microwave-assisted dipolar cycloaddition reactions of diazinium ylides with various dipolarophiles. Herein, we add further contributions to the field of using MW irradiation in organic chemistry [19-25], and propose a facile, efficient and environmentally friendly method for the synthesis of pyrrolodiazine derivatives using MW technologies.

\section{Results and Discussion}

The general approach adopted for the synthesis of fluorescent pyrrolodiazine derivatives is depicted in Scheme 1. As shown below, the preparation of all pyrrolodiazine derivatives, 7-11, involves two steps: initially N-alkylation of the diazine (pyridazine- $\mathrm{PY}$ or phthalazine- $\mathrm{PH}$ ) with bromoacetone 3 followed by a $3+2$ dipolar cycloaddition of diazinium ylides 6 (generated in situ in the presence of triehtylamine-TEA) from the corresponding salts to the corresponding dipolarophiles (dimethyl acetylenedicarboxylate-DMAD or methyl propiolate). Bromoacetone was synthesized, in a preliminary step, by the reaction of acetone with bromine in acetic acid as a catalyst.

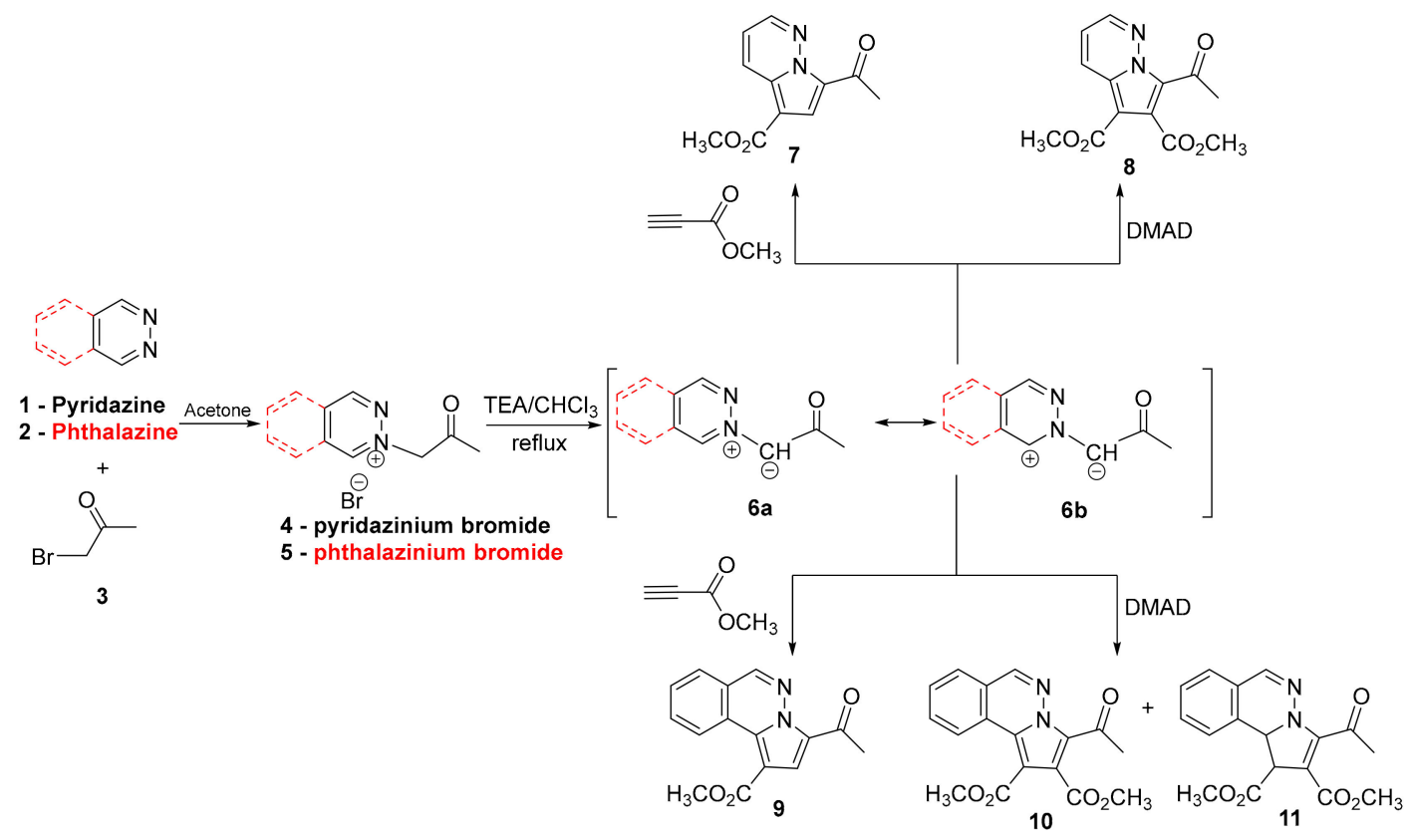

Scheme 1. Reaction pathway to generate pyrrolodiazine derivatives. DMAD = dimethyl acetylenedicarboxylate; TEA = triethylamine.

An alternative of this synthetic approach was used by Masaki and coworkers when investigating the cycloaddition reaction of pyridazinium ylides [26]. They performed the reaction in dimethylformamide (DMF) or benzene in the presence of TEA (in order to generate the ylide), the intermediate products being then oxidized with chloranil to obtain the fully aromatized cycloadducts $\mathbf{7}$ and $\mathbf{8}$ from Scheme 1 . The structure of the resulting pyrrolo[1,2-b]pyridazines has been determined by elemental and spectral analysis. Since the NMR data is presented in the work referenced above in a rather outdated manner (i.e., chemical shift was presented in $\tau$ and not in $\delta$, which is more actual), we chose to present a thorough spectral characterization of the compounds $\mathbf{7}$ and $\mathbf{8}$ in the experimental part of this work.

Another alternative to the synthetic approach was used by Dumitrascu and coworkers [27] in order to obtain pyrrolo[2,1-a]phthalazines. They performed the reaction at low temperature (ice-cooled) in the presence of TEA but obtained only the hydrogenated cycloadduct $\mathbf{1 1}$ from Scheme 1. In subsequent 
studies, Dumitrascu and coworkers [28] also obtained fully aromatized cycloadducts of type 9 and 10, but they use 1,2-epoxybutane (instead of TEA) which has the role of a solvent, to generate the corresponding ylide from the phthalazinium chlorides. However, in the two subsequent works, the authors were interested in the synthesis and elucidation of the molecular geometry and crystalline structure and did not approach the photophysical properties of these compounds.

In the current work, we performed the reactions in refluxing chloroform, and a chloroform solution of TEA was added dropwise at the beginning of the reaction. After $6 \mathrm{~h}$ of reflux, the reaction was stopped and the products were isolated from the reaction mixture. In the case of pyridazine, we only obtained the fully aromatized compounds $\mathbf{7}$ and $\mathbf{8}$. For phthalazine, the reaction with methyl propiolate yields the fully aromatized compound 9, while the reaction with DMAD gives a mixture of partial and fully aromatized compounds (11 and 10, respectively). All cycloadducts were obtained in moderate to good yield ( $74 \%$ to $81 \%$, see Table 1$)$. The results obtained by us in this study are in quantitative agreement with those published in the literature, including on the geometry of the hydrogenated cycloadduct 11. We note, however, besides the high energy consumption, the long reaction time (360 $\mathrm{min}$ ) is major disadvantage of the synthesis carried out under conventional conditions.

As an alternative route, we have performed the synthesis of the azaindolizine derivatives under MW irradiation, using a monomode reactor (Monowave 300; Anton Paar, Graz, Austria). This reactor is equipped with a stirring system ( 0 to $1200 \mathrm{rpm}$ ) and can reach up to $300^{\circ} \mathrm{C}$ with temperature control. The reactions take place in a closed vessel at 30 bars of maximum pressure. The optimal reaction conditions were found to be at $155^{\circ} \mathrm{C}$ and $16-17$ bars, and are summarized in Table 1 compared to the corresponding parameters used in thermal heating $(\mathrm{TH})$ conditions.

Table 1. The synthesis of pyrrolodiazine derivatives under microwave (MW) irradiation and conventional thermal heating $(\mathrm{TH})$.

\begin{tabular}{ccccc}
\hline \multirow{2}{*}{ Compound } & \multicolumn{2}{c}{ MW } & \multicolumn{2}{c}{ Conventional TH } \\
\cline { 2 - 5 } & $\begin{array}{c}\text { Reaction Time } \\
(\text { min) }\end{array}$ & Yield, \% & $\begin{array}{c}\text { Reaction Time } \\
(\mathbf{m i n})\end{array}$ & Yield, \% \\
\hline $\mathbf{7}$ & & 90 & & 77 \\
$\mathbf{8}$ & & 91 & & 74 \\
$\mathbf{9}$ & 10 & 94 & 360 & 81 \\
$\mathbf{1 0}$ & & 91 & & 45 \\
$\mathbf{1 1}$ & & 0 & & 37 \\
\hline
\end{tabular}

As indicated in Table 1, under MW irradiation, the reaction times decrease substantially from $6 \mathrm{~h}$ to $10 \mathrm{~min}$, whereas the solvent amounts used in the former were at least five times lower than the corresponding quantities used under conventional conditions (see Experimental section). This qualifies the former reactions as environmentally friendly. We also noticed that under MW irradiation, the yields were higher (by 10\% to 15\%). In the case of the reaction of phthalazinium bromide with DMAD, under microwave irradiation, we isolated only fully aromatized cycloadduct $\mathbf{1 0}$ with a $>91 \%$ yield.

Photophysical properties of the synthetized pyrrolodiazines were investigated using diluted solutions (less than $1 \times 10^{-5} \mathrm{~mol} / \mathrm{L}$ ) prepared in cyclohexane and dichloromethane, respectively. The dilution of each solution was adjusted and thus the absorbances, measured at $360 \mathrm{~nm}, 320 \mathrm{~nm}$ and $370 \mathrm{~nm}$ and reported on a $10 \mathrm{~mm}$ cuvette, to fit in the range of $0.02-0.20$ units.

The optical absorption and emission maxima with corresponding quantum yield of the pyrrolodiazine derivatives in cyclohexane and dichloromethane are summarized in Table 2. 
Table 2. $\lambda_{\max }(\mathrm{nm})$ of absorption spectra, $\lambda_{\max }(\mathrm{nm})$ of emission spectra, and relative quantum yields (\%) of compounds 7-11.

\begin{tabular}{ccccc}
\hline \multirow{2}{*}{ Compound } & \multicolumn{2}{c}{$\begin{array}{c}\text { Fluorescence }\left(\lambda_{\max }, \mathbf{n m}\right) \\
\text { (Quantum Yields }(\%))\end{array}$} & \multicolumn{2}{c}{ Absorption $\left(\boldsymbol{\lambda}_{\text {max }}, \mathbf{n m}\right)$} \\
\cline { 2 - 5 } & Cyclohexane & Dichloromethane & Cyclohexane & Dichloromethane \\
\hline $\mathbf{7}$ & $426(24)$ & $432(21)$ & 360 & 358 \\
$\mathbf{8}$ & $422(25)$ & $426(26)$ & 356 & 354 \\
$\mathbf{9}$ & $428(7)$ & $441(5)$ & 327 & 325 \\
$\mathbf{1 0}$ & $439(6)$ & $446(4)$ & 324 & 322 \\
$\mathbf{1 1}$ & 491 & - & 374 & 372 \\
\hline
\end{tabular}

$\lambda_{\text {exe }}=360 \mathrm{~nm}$ for samples 7 and $8 ; \lambda_{\text {exe }}=320 \mathrm{~nm}$ for samples $\mathbf{9}$ and $10 ; \lambda_{\text {exe }}=370 \mathrm{~nm}$ for sample 11. $\left(\lambda_{\max }=\right.$ maximum absorption or emission wavelength; $\lambda_{\text {exe }}=$ excitation wavelength).

Table 2 shows that compounds $\mathbf{7}$ and $\mathbf{8}$ are moderate blue emitters $\left(\lambda_{\max }\right.$ of fluorescence around $420-430 \mathrm{~nm}$, with quantum yields around $25 \%$ ), compounds 9 and 10 are still blue emitters $\left(\lambda_{\max }\right.$ of fluorescence around $425-440 \mathrm{~nm}$, with lower quantum yields-around 5\%), while for compound 11, the fluorescence intensity is negligible and the emission is substantially red shifted, with a maximum of the emission band (measurable only in cyclohexane) around $490 \mathrm{~nm}$. Such a deviation from the trends shown in Table 2 should relate to the difference in the electronic structures of $\mathbf{7 - 1 0}$ (aromatic and fully conjugated), and $\mathbf{1 1}$ that lacks a full electron conjugation.

It is the fluorescence emission of the fully aromatized compounds such as 7-10 that justifies the interest in synthesizing pyrrolodiazines. However, for most of the anticipated applications, including their use as fluorescent markers, choosing a feasible derivatization reaction is important in order to incorporate them into biological macromolecules (peptides, proteins and DNA). Hence, taking into account that the carbonyl group can be easily halogenated in the $\alpha$-position, and that the resulting derivatives should present an enhanced reactivity, we decided in the next step to investigate the bromination reaction of pyrrolodiazines 7-10 (shown in Scheme 2). The procedure chosen has been reported previously by us in [29], and consists of bromination in heterogeneous catalysis using copper (II) bromide in chloroform/ethyl acetate. This reaction system is highly regioselective, leading to $\alpha$-bromo derivatives in good yields, but less selective regarding to the resulting mono- or di-brominated product. Using this procedure, we performed the bromination of compounds $\mathbf{7 - 1 0}$ with copper (II) bromide, both under conventional TH and MW irradiation, in order to study the reaction selectivity. In Table 3, we list the optimized conditions that were employed.
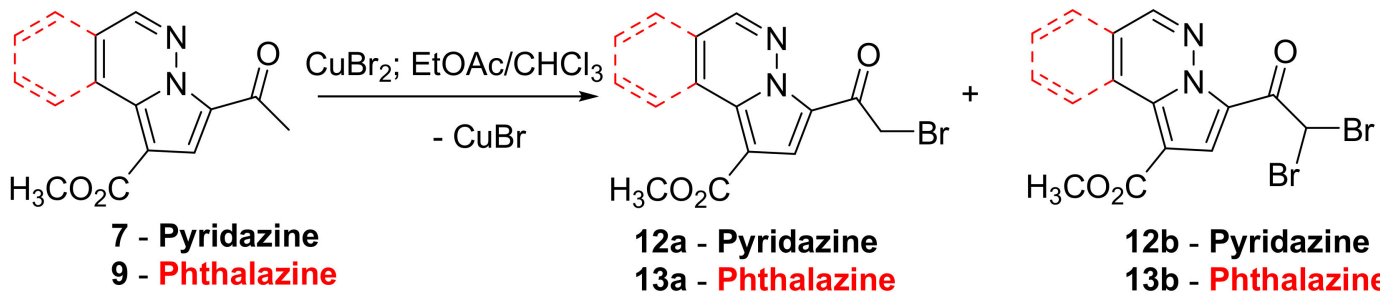

12b - Pyridazine 13b - Phthalazine<smiles></smiles>
EtOAc - Ethyl acetate<smiles>COC(=O)c1c(C(=O)OC)c2c3ccccc3cnn2c1C(=O)C(Br)Br</smiles> 
Table 3. Synthesis of $\alpha$-brominated pyrrolodiazine, under MW and TH conditions.

\begin{tabular}{ccccc}
\hline \multirow{2}{*}{ Compound } & \multicolumn{2}{c}{ MW } & \multicolumn{2}{c}{ Conventional TH } \\
\cline { 2 - 5 } & $\begin{array}{c}\text { Reaction Time } \\
(\mathbf{m i n})\end{array}$ & Yield, \% & $\begin{array}{c}\text { Reaction Time } \\
\text { (min) }\end{array}$ & Yield, \% \\
\hline $\mathbf{1 2 a}$ & & 77 & & 53 \\
$\mathbf{1 2 b}$ & & 12 & & 17 \\
$\mathbf{1 3 a}$ & & 76 & & 50 \\
$\mathbf{1 3 b}$ & 20 & 11 & 480 & 16 \\
$\mathbf{1 4 a}$ & & 77 & & 55 \\
$\mathbf{1 4 b}$ & & 13 & & 17 \\
$\mathbf{1 5 a}$ & & 75 & & 49 \\
$\mathbf{1 5 b}$ & & 12 & & 16 \\
\hline
\end{tabular}

As shown in Table 3, the microwave-assisted bromination of pyrrolodiazine derivatives $\mathbf{7 - 1 0}$ occurred with the expected regioselectivity (only in the $\alpha$-position) and with increased selectivity regarding to the monobrominated compound. The ratio between mono- and di-brominated compounds was around 3:1 under thermal heating, and 6:1 under unconventional heating. The yields were moderate under conventional TH and good under MW irradiation, which showed a significant increase of yields (an average of $15-20 \%$ ).

\section{Experimental Section}

\subsection{General Procedure}

All the reagents and solvents were purchased from commercial sources and used without further purification (except bromoacetone, which was synthesized by the reaction of acetone with bromine in acetic acid as a catalyst). Melting points were recorded on an Electrothermal MEL-TEMP (Barnstead International, Dubuque, IA, USA) apparatus in open capillary tubes and are uncorrected. Analytical thin-layer chromatography was performed with commercial silica gel plates 60 F254 (Merck Darmstadt, Germany) and visualized with UV light. The NMR spectra were recorded on an Avance III $500 \mathrm{MHz}$ spectrometer (Bruker, Vienna, Austria) operating at $500 \mathrm{MHz}$ for ${ }^{1} \mathrm{H}$ and $125 \mathrm{MHz}$ for ${ }^{13} \mathrm{C}$. The following abbreviations were used to designate chemical shift multiplicities: $\mathrm{s}=$ singlet, $\mathrm{d}=$ doublet $\mathrm{t}=$ triplet, $\mathrm{m}=$ multiplet. Chemical shifts were reported in delta $(\delta)$ units, part per million (ppm) and coupling constants $(J)$ in Hz. Infrared (IR) data were recorded as films on potassium bromide (KBr) pellets on a FT-IR Prestige 8400s spectrophotometer (Shimadzu, Kyoto, Japan). For the microwave irradiation, we used a monomode reactor (Monowave 300; Anton Paar, Graz, Austria). This reactor can reach up to $300{ }^{\circ} \mathrm{C}$ and controls the temperature via a built-in IR sensor. Some additional specifications of the Monowave 300 include: microwave power $=850 \mathrm{~W}$, operation limits at $300{ }^{\circ} \mathrm{C}$ and 30 bars, reaction vial = borosilicate, operation volume = between $0.5-20 \mathrm{~mL}$, pressure control by hydraulic system, agitation with an integrated magnetic stirrer (0 to $1200 \mathrm{rpm}$ ) and cooling with compressed air. UV-Vis spectra were recorded on a Shimadzu 1800 PC spectrophotometer in cyclohexane and dichloromethane (spectroscopic grade) solution. The fluorescence measurements were made using a F900 photoluminescence spectrometer (Edinburgh Instruments, Livingstone, UK) in the same solvents as for the UV-Vis spectra, with the excitation wavelength set to the absorption band maximum. For all spectral determinations, the solutions were kept in $10 \mathrm{~mm}$ path length quartz cells. The fluorescence quantum yield was determined at room temperature with a FLS 980 fluorimeter (Edinburgh Instruments) with an integrating sphere and the excitation wavelength corresponds to the maximum of the absorption band. 
3.1.1. General Procedure for Synthesis of Pyrrolodiazine Derivatives 7-11 under Conventional TH Conditions and MW Irradiation

A mixture of diazinium salt 4 or $5(0.543 \mathrm{~g}, 2.5 \mathrm{mmol}$ for pyridazinium bromide 4 or $0.668 \mathrm{~g}$, $2.5 \mathrm{mmol}$ for phthalazinium bromide 5) and dimethyl acetylenedicarboxylate $(0.43 \mathrm{~mL}, 3.5 \mathrm{mmol})$ or methyl propiolate $(0.31 \mathrm{~mL}, 3.5 \mathrm{mmol})$ was suspended in $35 \mathrm{~mL}$ chloroform. Then, triethylamine $(0.48 \mathrm{~mL}, 3.5 \mathrm{mmol})$ dissolved in $15 \mathrm{~mL}$ chloroform was added dropwise under stirring and refluxing in one hour. The stirring and refluxing were continued for $360 \mathrm{~min}$. After the reaction was finished (TLC), the obtained solution was cooled down to room temperature and then the reaction mixtures were washed with water $(3 \times 25 \mathrm{~mL})$, dried over magnesium sulfate and evaporated under reduced pressure to give the crude product. The purification of the crude product was done by column chromatography on silica gel (eluted with 99.5/0.5 $\mathrm{CH}_{2} \mathrm{Cl}_{2} / \mathrm{CH}_{3} \mathrm{OH}$ ).

Under MW irradiation, the mixture of reagents (in $10 \mathrm{~mL}$ chloroform) was placed into the reaction vessel and exposed to irradiation for $10 \mathrm{~min}$. Using MW irradiation, the best results were obtained using a "temperature control" method. The "temperature control" method ensures a constant temperature (in this case $100^{\circ} \mathrm{C}$ ) to vary the magnetron power. This method takes place in three stages. In the first step, the temperature is raised as quickly as possible (within less than $1 \mathrm{~min}$ ) by applying maximum power. In the second step, the reaction mixture is kept at a constant temperature with the control of the magnetron power. In the last step, the reaction tube is cooled to $55^{\circ} \mathrm{C}$ by stopping the irradiation and blowing the reaction vial with compressed air. Once the heating cycle is completed, the reaction vial is removed from the reactor and processed as indicated for TH. The NMR spectra and IR Spectra of the obtained compounds are in the Supplementary Materials.

3.1.2. General Procedure for Synthesis of $\alpha$-brominated Pyrrolodiazines 12-15 under Conventional TH Conditions and MW Irradiation

The pyrrolodiazine derivatives 7-10 ( $1 \mathrm{mmol}, 0.218 \mathrm{~g}$ for cycloadduct 7; $0.276 \mathrm{~g}$ for cycloadduct 8; $0.268 \mathrm{~g}$ for cycloadduct $9 ; 0.326 \mathrm{~g}$ for cycloadduct 10 ) dissolved in $10 \mathrm{~mL}$ of a mixture of chloroform/ethyl acetate, were added dropwise under stirring and refluxing in one hour to a suspension of copper (II) bromide ( $2 \mathrm{mmol}, 0.448 \mathrm{~g}$ ) in a $20 \mathrm{~mL}$ mixture of chloroform/ethyl acetate at a 1:2 ratio (pyrrolodiazine derivatives 7-10 / copper (II) bromide). The stirring and refluxing were continued for $480 \mathrm{~min}$. The hot solution was filtered in order to remove the copper (I) bromide that formed. The solvent was evaporated by vacuum distillation. The crude product was purified by column chromatography on a silica gel (eluted with dichloromethane).

Under MW irradiation, the pyrrolodiazine derivatives 7-10 (1 mmol, $0.218 \mathrm{~g}$ for cycloadduct 7; $0.276 \mathrm{~g}$ for cycloadduct $8 ; 0.268 \mathrm{~g}$ for cycloadduct $9 ; 0.326 \mathrm{~g}$ for cycloadduct 10 ) and copper (II) bromide ( $2 \mathrm{mmol}, 0.448 \mathrm{~g}$ ) were mixed at a 1:2 ratio (pyrrolodiazine derivatives 7-10/copper (II) bromide) in 10 $\mathrm{mL}$ solvent (chloroform/ethylacetate). This mixture was then placed in the reaction vessel and exposed to irradiation for $20 \mathrm{~min}$. Using MW irradiation, the best results were obtained using a "temperature control" method. The "temperature control" method ensures a constant temperature (in this case 120 ${ }^{\circ} \mathrm{C}$ ) while varying the magnetron power. Once the heating cycle was completed, the reaction tube was cooled to ambient temperature, removed from the reactor, and processed as indicated for $\mathrm{TH}$.

Methyl 7-acetylpyrrolo[1,2-b]pyridazine-5-carboxylate (7). $0.42 \mathrm{~g}, 77 \%$ (under classical heating) and $0.49 \mathrm{~g}$, $90 \%$ (under microwave) as white crystals, m.p. $138-140{ }^{\circ} \mathrm{C} ; R_{\mathrm{f}}\left(98 / 2 \mathrm{CH}_{2} \mathrm{Cl}_{2} / \mathrm{CH}_{3} \mathrm{OH}\right) 0.37 ; \mathrm{IR}\left(\mathrm{cm}^{-1}\right)$ : 3111, 3103, 3066 (C-H arom.), 2953 (C-H aliph.), 1701 (C=O, ester), 1659 (C=O, keto), 1616, 1529, 1519, 1448, 1379 (aromatic and heteroaromatic ring), 1282, 1249, 1211, 1176, 1122 (C-O-C, ester); ${ }^{1} \mathrm{H}$ NMR $\left(500 \mathrm{MHz} \mathrm{CDCl}_{3}\right): \delta 8.65(1 \mathrm{H}, \mathrm{dd}, J=2.0,9.0 \mathrm{~Hz}, \mathrm{H}-2), 8.51(1 \mathrm{H}, \mathrm{dd}, J=2.0,4.0 \mathrm{~Hz}, \mathrm{H}-4), 8.02(1 \mathrm{H}, \mathrm{s}$, $\mathrm{H}-6), 7.12(1 \mathrm{H}, \mathrm{dd}, J=4.0,9.0 \mathrm{~Hz}, \mathrm{H}-3), 3.93\left(3 \mathrm{H}, \mathrm{s}, \mathrm{CH}_{3}\right.$ of methoxycarbonyl group from 5 position), $2.71\left(3 \mathrm{H}, \mathrm{s}, \mathrm{CH}_{3}\right.$ of acetyl group from 7 position); ${ }^{13} \mathrm{C} \mathrm{NMR}\left(125 \mathrm{MHz}, \mathrm{CDCl}_{3}\right): \delta 187.4$ (CO keto group from 7 position), 164.0 (CO keto ester from 5 position), 144.2 (C-4), 133.2 (C-4a), 128.2 (C-2), 128.1 (C-7), 123.0 (C-6), 117.3 (C-3), 105.4 (C-5), 51.7 ( $\mathrm{CH}_{3}$ of methoxycarbonyl group from 5 position), 29.5 ( $\mathrm{CH}_{3}$ of acetyl group from 7 position). All spectral data are in agreement with the previously reported data [26]. 
Dimethyl 7-acetylpyrrolo[1,2-b]pyridazine-5,6-dicarboxylate (8). $0.51 \mathrm{~g}, 74 \%$ (under classical heating) and $0.63 \mathrm{~g}, 91 \%$ (under microwaves) as white crystals, m.p. $197-198{ }^{\circ} \mathrm{C} ; \mathrm{R}_{\mathrm{f}}\left(98 / 2 \mathrm{CH}_{2} \mathrm{Cl}_{2} / \mathrm{CH}_{3} \mathrm{OH}\right) 0.38$; IR (cm $\left.{ }^{-1}\right)$ : 3082, 3064, 3010 (C-H arom.), 2957 (C-H aliph.), 1743, 1705 (C=O, ester), 1660 (C=O, keto), $1614,1535,1500,1452,1381$ (aromatic and heteroaromatic ring), 1313, 1269, 1244, 1211, 1168, 1130, 1072 (C-O-C, ester); ${ }^{1} \mathrm{H}$ NMR (500 MHz, $\left.\mathrm{CDCl}_{3}\right): \delta 8.65(1 \mathrm{H}, \mathrm{dd}, J=2.0,9.0 \mathrm{~Hz}, \mathrm{H}-2), 8.46(1 \mathrm{H}, \mathrm{dd}, J=2.0$, $4.5 \mathrm{~Hz}, \mathrm{H}-4), 7.14(1 \mathrm{H}, \mathrm{dd}, J=4.5,9.0 \mathrm{~Hz}, \mathrm{H}-3), 4.02\left(3 \mathrm{H}, \mathrm{s}, \mathrm{CH}_{3}\right.$ of methoxycarbonyl group from 5 position), $3.92\left(3 \mathrm{H}, \mathrm{s}, \mathrm{CH}_{3}\right.$ of methoxycarbonyl group from 6 position), $2.81\left(3 \mathrm{H}, \mathrm{s}, \mathrm{CH}_{3}\right.$ of acetyl group from 7 position); $\left.{ }^{13} \mathrm{C} \mathrm{NMR} \mathrm{(125} \mathrm{MHz,} \mathrm{CDCl}_{3}\right): \delta 187.7$ (CO keto group from 7 position), 166.0 (CO keto ester from 6 position), 162.8 (CO keto ester from 5 position), 144.3 (C-4), 131.3 (C-4a), 128.8 (C-2), 128.1 (C-7), 126.8 (C-6), 117.3 (C-3), 103.4 (C-5), 53.1 ( $\mathrm{CH}_{3}$ of methoxycarbonyl group from 6 position), $51.9\left(\mathrm{CH}_{3}\right.$ of methoxycarbonyl group from 5 position), $31.0\left(\mathrm{CH}_{3}\right.$ of acetyl group from 7 position). All spectral data are in agreement with the previously reported data [26].

Methyl 3-Aetylpyrrolo[2,1-a]phthalazine-1-carboxylate (9). $0.54 \mathrm{~g}, 81 \%$ (under classical heating) and 0.63 g, $94 \%$ (under microwaves) as white crystals, m.p. $194-195{ }^{\circ} \mathrm{C} ; R_{\mathrm{f}}\left(98 / 2 \mathrm{CH}_{2} \mathrm{Cl}_{2} / \mathrm{CH}_{3} \mathrm{OH}\right) 0.38$. All spectral data are in agreement with the previously reported data [28].

Dimethyl 3-acetylpyrrolo[2,1-a]phthalazine-1,2-dicarboxylate (10). $0.37 \mathrm{~g}$, 45\% (under classical heating) and $0.74 \mathrm{~g}, 91 \%$ (under microwaves) as white crystals, m.p. $148-150{ }^{\circ} \mathrm{C} ; \mathrm{R}_{\mathrm{f}}\left(98 / 2 \mathrm{CH}_{2} \mathrm{Cl}_{2} / \mathrm{CH}_{3} \mathrm{OH}\right) 0.40$. All spectral data are in agreement with the previously reported one [28].

Dimethyl 3-acetyl-1,10b-dihydropyrrolo[2,1-a]phthalazine-1,2-dicarboxylate (11). $0.30 \mathrm{~g}$, 37\% (under classical heating) and $0.0 \mathrm{~g}, 0 \%$ (under microwaves) as yellow crystals, m.p. $138-139^{\circ} \mathrm{C} ; \mathrm{R}_{\mathrm{f}}\left(98 / 2 \mathrm{CH}_{2} \mathrm{Cl}_{2} / \mathrm{CH}_{3} \mathrm{OH}\right)$ 0.50. All spectral data are in agreement with the previously reported data [27].

Methyl 7-(2-bromoacetyl)pyrrolo[1,2-b]pyridazine-5-carboxylate (12a). $0.16 \mathrm{~g}, 53 \%$ (under classical heating) and $0.23 \mathrm{~g}, 77 \%$ (under microwaves) as yellowish crystals, m.p. $140-141{ }^{\circ} \mathrm{C} ; R_{\mathrm{f}}\left(99 / 1 \mathrm{CH}_{2} \mathrm{Cl}_{2} / \mathrm{CH}_{3} \mathrm{OH}\right)$ 0.33; IR ( $\mathrm{cm}^{-1}$ ): 3090, 3074, 3010 (C-H arom.), 2955, 2924 (C-H aliph.), 1707 (C=O, ester), 1654 (C=O, keto), 1529, 1471, 1450, 1379 (aromatic and heteroaromatic ring), 1286, 1263, 1226, 1197, 1136 (C-O-C, ester), $582(\mathrm{C}-\mathrm{Br}) ;{ }^{1} \mathrm{H}$ NMR $\left(500 \mathrm{MHz} \mathrm{CDCl}_{3}\right): \delta 8.66(1 \mathrm{H}, \mathrm{dd}, J=1.5,9.0 \mathrm{~Hz}, \mathrm{H}-2), 8.51(1 \mathrm{H}, \mathrm{dd}, J=1.5$, $4.5 \mathrm{~Hz}, \mathrm{H}-4), 8.11(1 \mathrm{H}, \mathrm{s}, \mathrm{H}-6), 7.16(1 \mathrm{H}, \mathrm{dd}, J=4.5,9.0 \mathrm{~Hz}, \mathrm{H}-3), 4.64\left(2 \mathrm{H}, \mathrm{s}, \mathrm{CH}_{2}\right.$ of bromoacetyl group from 7 position), $3.92\left(3 \mathrm{H}, \mathrm{s}, \mathrm{CH}_{3}\right.$ of methoxycarbonyl group from 5 position); ${ }^{13} \mathrm{C} \mathrm{NMR}(125 \mathrm{MHz}$, $\mathrm{CDCl}_{3}$ ): $\delta 181.0$ (CO keto group from 7 position), 163.7 (CO keto ester from 5 position), 144.3 (C-4), 133.5 (C-4a), 128.4 (C-2), 126.0 (C-7), 123.6 (C-6), 117.6 (C-3), 106.4 (C-5), 51.8 ( $\mathrm{CH}_{3}$ of methoxycarbonyl group from 5 position), 34.2 ( $\mathrm{CH}_{2}$ of bromoacetyl group from 7 position).

Methyl 7-(2,2-dibromoacetyl)pyrrolo[1,2-b]pyridazine-5-carboxylate (12b). $0.064 \mathrm{~g}, 17 \%$ (under classical heating) and $0.045 \mathrm{~g}, 12 \%$ (under microwaves) as yellowish crystals, m.p. $150-151{ }^{\circ} \mathrm{C} ; R_{\mathrm{f}}(99 / 1$ $\mathrm{CH}_{2} \mathrm{Cl}_{2} / \mathrm{CH}_{3} \mathrm{OH}$ ) 0.58; IR (cm ${ }^{-1}$ ): 3095, 3061, 3049, 3034 (C-H arom.), 2945 (C-H aliph.), 1710 (C=O, ester), 1666 (C=O, keto), 1535, 1518, 1467, 1442, 1415 (aromatic and heteroaromatic ring), 1253, 1234, 1203, 1165, 1138 (C-O-C, ester), 663, 621 (C-Br); ${ }^{1} \mathrm{H}$ NMR (500 MHz, CDCl $): \delta 8.70(1 \mathrm{H}, \mathrm{dd}, J=2.0,9.0$ $\mathrm{Hz}, \mathrm{H}-2), 8.55(1 \mathrm{H}, \mathrm{dd}, J=2.0,4.5 \mathrm{~Hz}, \mathrm{H}-4), 8.27(1 \mathrm{H}, \mathrm{s}, \mathrm{H}-6), 7.35(1 \mathrm{H}, \mathrm{s}, \mathrm{CH}$ of dibromoacetyl group from 7 position), $7.20(1 \mathrm{H}, \mathrm{dd}, J=4.5,9.0 \mathrm{~Hz}, \mathrm{H}-3), 3.94\left(3 \mathrm{H}, \mathrm{s}, \mathrm{CH}_{3}\right.$ of methoxycarbonyl group from 5 position); ${ }^{13} \mathrm{C}$ NMR (125 $\mathrm{MHz} \mathrm{CDCl}_{3}$ ): $\delta 176.2$ (CO keto group from 7 position), 163.6 (CO keto ester from 5 position), 144.4 (C-4), 134.7 (C-4a), 134.1 (C-7), 128.7 (C-2), 124.9 (C-6), 117.8 (C-3), 107.2 (C-5), $51.9\left(\mathrm{CH}_{3}\right.$ of methoxycarbonyl group from 5 position), 42.5 ( $\mathrm{CH}$ of dibromoacetyl group from 7 position).

Methyl 3-(2-bromoacetyl)pyrrolo[2,1-a]phthalazine-1-carboxylate (13a). $0.17 \mathrm{~g}, 50 \%$ (under classical heating) and $0.26 \mathrm{~g}, 76 \%$ (under microwaves) as yellowish crystals, m.p. $155-156{ }^{\circ} \mathrm{C} ; R_{\mathrm{f}}\left(99 / 1 \mathrm{CH}_{2} \mathrm{Cl}_{2} / \mathrm{CH}_{3} \mathrm{OH}\right)$ 0.51; IR ( $\left.\mathrm{cm}^{-1}\right)$ : 3115, 3039, 3020 (C-H arom.), 2949, 2904 (C-H aliph.), 1703 (C=O, ester), 1662 (C=O, keto), 1554, 1529, 1487, 1450, 1375 (aromatic and heteroaromatic ring), 1255, 1188, 1172, 1143, 1089 (C-O-C, ester), 609 (C-Br); ${ }^{1} \mathrm{H}$ NMR $\left(500 \mathrm{MHz}, \mathrm{CDCl}_{3}\right): \delta 9.82(1 \mathrm{H}, \mathrm{d}, J=8.5 \mathrm{~Hz}, \mathrm{H}-10), 8.75(1 \mathrm{H}, \mathrm{s}$, H-6), 8.14 (1H, s, H-2), 7.90-7.94 (2H, m, H-7, H-9), $7.77(1 \mathrm{H}, \mathrm{dd}, J=7.0,8.0 \mathrm{~Hz}, \mathrm{H}-8), 4.72\left(2 \mathrm{H}, \mathrm{s}, \mathrm{CH}_{2}\right.$ 
of bromoacetyl group from 3 position), 3.97 (3H, s, $\mathrm{CH}_{3}$ of methoxycarbonyl group from 1 position); ${ }^{13} \mathrm{C}$ NMR (125 MHz, $\mathrm{CDCl}_{3}$ ): $\delta 181.6$ (CO keto group from 3 position), 164.6 (CO keto ester from 1 position), 146.5 (C-6), 133.5 (C-9), 130.3 (C-10b), 130.2 (C-8), 127.8 (C-7),127.7 (C-10), 126.9 (C-10a), 126.3 (C-3), 124.0 (C-2), 121.9 (C-6a), 109.3 (C-1), 52.2 ( $\mathrm{CH}_{3}$ of methoxycarbonyl group from 1 position), 34.8 $\left(\mathrm{CH}_{2}\right.$ of bromoacetyl group from 3 position).

Methyl 3-(2,2-dibromoacetyl)pyrrolo[2,1-a]phthalazine-1-carboxylate (13b). $0.068 \mathrm{~g}, 16 \%$ (under classical heating) and $0.047 \mathrm{~g}, 11 \%$ (under microwaves) as yellowish crystals, m.p. $192-193{ }^{\circ} \mathrm{C} ; R_{\mathrm{f}}(99 / 1$ $\left.\mathrm{CH}_{2} \mathrm{Cl}_{2} / \mathrm{CH}_{3} \mathrm{OH}\right)$ 0.72; IR (cm ${ }^{-1}$ ): 3113, 3043, 3018, 2997 (C-H arom.), 2947(C-H aliph.), 1720 (C=O, ester), 1678 (C=O, keto), 1531, 1462, 1448, 1404, 1379 (aromatic and heteroaromatic ring), 1265, 1240, 1178, 1143 (C-O-C, ester), 663, 624 (C-Br); ${ }^{1} \mathrm{H}$ NMR (500 MHz, CDCl $\left.{ }_{3}\right): \delta 9.81(1 \mathrm{H}, \mathrm{d}, J=8.0 \mathrm{~Hz}, \mathrm{H}-10)$, 8.78 (1H, s, H-6), 8.26 (1H, s, H-2), 7.92-7.96 (2H, m, H-7, H-9), 7.80 (1H, dd, J = 7.0, 7.5 Hz, H-8), 7.49 $\left(1 \mathrm{H}, \mathrm{s}, \mathrm{CH}\right.$ of dibromoacetyl group from 3 position), $3.98\left(3 \mathrm{H}, \mathrm{s}, \mathrm{CH}_{3}\right.$ of methoxycarbonyl group from 1 position); ${ }^{13} \mathrm{C}$ NMR (125 $\left.\mathrm{MHz} \mathrm{CDCl}_{3}\right): \delta 176.7$ (CO keto group from 3 position), 164.4 (CO keto ester from 1 position), 146.6 (C-6), 133.7 (C-9), 130.9 (C-10b), 130.4 (C-8), 127.9 (C-7),127.9 (C-10), 126.9 (C-10a), 125.5 (C-2), 122.8 (C-3), 121.9 (C-6a), 110.0 (C-1), 52.2 ( $\mathrm{CH}_{3}$ of methoxycarbonyl group from 1 position), 43.1 (CH of dibromoacetyl group from 3 position).

Dimethyl 7-(2-bromoacetyl)pyrrolo[1,2-b]pyridazine-5,6-dicarboxylate (14a). $0.20 \mathrm{~g}$, 55\% (under classical heating) and $0.27 \mathrm{~g}, 77 \%$ (under microwaves) as yellowish crystals, m.p. $177-178{ }^{\circ} \mathrm{C} ; R_{\mathrm{f}}(99 / 1$ $\mathrm{CH}_{2} \mathrm{Cl}_{2} / \mathrm{CH}_{3} \mathrm{OH}$ ) 0.28; IR (cm ${ }^{-1}$ ): 3132, 3099, 3001 (C-H arom.), 2951, 2924 (C-H aliph.), 1749, 1714 $(\mathrm{C}=\mathrm{O}$, ester), 1660 ( $\mathrm{C}=\mathrm{O}$, keto), 1502, 1450, 1427, 1381 (aromatic and heteroaromatic ring), 1249, 1228, 1190, 1170, 1116 (C-O-C, ester), 580 (C-Br); ${ }^{1} \mathrm{H}$ NMR (500 MHz, DMSO): $\delta 8.83$ (1H, dd, J = 1.5, 4.5 $\mathrm{Hz}, \mathrm{H}-2), 8.65(1 \mathrm{H}, \mathrm{dd}, J=1.5,9.0 \mathrm{~Hz}, \mathrm{H}-4), 7.50(1 \mathrm{H}, \mathrm{dd}, J=4.5,9.0 \mathrm{~Hz}, \mathrm{H}-3), 5.02\left(2 \mathrm{H}, \mathrm{s}, \mathrm{CH}_{2}\right.$ of bromoacetyl group from 7 position), $3.88\left(3 \mathrm{H}, \mathrm{s}, \mathrm{CH}_{3}\right.$ of methoxycarbonyl group from 5 position), $3.85\left(3 \mathrm{H}, \mathrm{s}, \mathrm{CH}_{3}\right.$ of methoxycarbonyl group from 6 position); ${ }^{13} \mathrm{C}$ NMR (125 MHz, DMSO): $\delta 180.6$ (CO keto group from 7 position), 164.8 (CO keto ester from 6 position), 161.9 (CO keto ester from 5 position), 145.8 (C-4), 131.1 (C-4a), 128.5 (C-2), 128.4 (C-7), 123.6 (C-6), 119.4 (C-3), 102.9 (C-5), $52.6\left(\mathrm{CH}_{3}\right.$ of methoxycarbonyl group from 6 position), $51.9\left(\mathrm{CH}_{3}\right.$ of methoxycarbonyl group from 5 position), $37.5\left(\mathrm{CH}_{2}\right.$ of bromoacetyl group from 7 position).

Dimethyl 7-(2,2-dibromoacetyl)pyrrolo[1,2-b]pyridazine-5,6-dicarboxylate (14b). 0.074 g, 17\% (under classical heating) and $0.056 \mathrm{~g}, 13 \%$ (under microwaves) as yellowish crystals, m.p. $181-182{ }^{\circ} \mathrm{C} ; R_{\mathrm{f}}(99 / 1$ $\mathrm{CH}_{2} \mathrm{Cl}_{2} / \mathrm{CH}_{3} \mathrm{OH}$ ) 0.33; IR (cm ${ }^{-1}$ ): 3099, 3051, 3024 (C-H arom.), 2953 (C-H aliph.), 1735, 1712 (C=O, ester), 1656 (C=O, keto), 1535, 1502, 1440, 1423, 1390 (aromatic and heteroaromatic ring), 1271, 1251, 1224, 1203, 1176, 1114 (C-O-C, ester), 590, 547 (C-Br); ${ }^{1} \mathrm{H}$ NMR (500 MHz, CDCl $): \delta 8.72(1 \mathrm{H}, \mathrm{dd}, J$ $=1.5,9.5 \mathrm{~Hz}, \mathrm{H}-2), 8.57(1 \mathrm{H}, \mathrm{dd}, J=1.5,4.5 \mathrm{~Hz}, \mathrm{H}-4), 7.62(1 \mathrm{H}, \mathrm{s}, \mathrm{CH}$ of dibromoacetyl group from 7 position), $7.25(1 \mathrm{H}, \mathrm{dd}, J=4.5,9.5 \mathrm{~Hz}, \mathrm{H}-3), 4.05\left(3 \mathrm{H}, \mathrm{s}, \mathrm{CH}_{3}\right.$ of methoxycarbonyl group from 5 position), $3.92\left(3 \mathrm{H}, \mathrm{s}, \mathrm{CH}_{3}\right.$ of methoxycarbonyl group from 6 position); $\left.{ }^{13} \mathrm{C} \mathrm{NMR} \mathrm{(125} \mathrm{MHz} \mathrm{CDCl}_{3}\right)$ : $\delta 176.0$ (CO keto group from 7 position), 165.1 (CO keto ester from 6 position), 162.4 (CO keto ester from 5 position), 145.0 (C-4), 132.5 (C-4a), 131.4 (C-7), 129.4 (C-2), 120.5 (C-6), 118.3 (C-3), 105.2 (C-5), $53.5\left(\mathrm{CH}_{3}\right.$ of methoxycarbonyl group from 6 position), $52.3\left(\mathrm{CH}_{3}\right.$ of methoxycarbonyl group from 5 position), 43.0 ( $\mathrm{CH}$ of dibromoacetyl group from 7 position).

Dimethyl 3-(2-bromoacetyl)pyrrolo[2,1-a]phthalazine-1,2-dicarboxylate (15a). 0.20 g, 49\% (under classical heating) and $0.30 \mathrm{~g}, 75 \%$ (under microwaves) as yellowish crystals, m.p. $159-160{ }^{\circ} \mathrm{C} ; R_{\mathrm{f}}(99 / 1$ $\mathrm{CH}_{2} \mathrm{Cl}_{2} / \mathrm{CH}_{3} \mathrm{OH}$ ) 0.42; IR (cm ${ }^{-1}$ ): 3119, 3045, 3026, 2995 (C-H arom.), 2949 (C-H aliph.), 1722 (C=O, ester), 1664 (C=O, keto), 1552, 1527, 1500, 1467, 1388 (aromatic and heteroaromatic ring), 1259, 1234, 1195, 1168, 1114 (C-O-C, ester), 611 (C-Br); ${ }^{1} \mathrm{H}$ NMR (500 MHz, CDCl $): \delta 9.53(1 \mathrm{H}, \mathrm{d}, J=8.5 \mathrm{~Hz}$, H-10), 8.73 (1H, s, H-6), 7.90-7.93 (2H, m, H-7, H-9), 7.78 (1H, dd, J = 7.0, 7.5 Hz, H-8), 4.85 (2H, s, CH of bromoacetyl group from 3 position), $4.02\left(3 \mathrm{H}, \mathrm{s}, \mathrm{CH}_{3}\right.$ of methoxycarbonyl group from 1 position), $3.94\left(3 \mathrm{H}, \mathrm{s}, \mathrm{CH}_{3}\right.$ of methoxycarbonyl group from 2 position); ${ }^{13} \mathrm{C} \mathrm{NMR}\left(125 \mathrm{MHz}, \mathrm{CDCl}_{3}\right): \delta 181.7(\mathrm{CO}$ 
keto group from 3 position), 166.0 (CO keto ester from 2 position), 163.7 (CO keto ester from 1 position), 147.0 (C-6), 133.9 (C-9), 130.4 (C-8), 128.7 (C-3), 128.3 (C-10b), 128.2 (C-7), 127.3 (C-10), 126.7 (C-10a), 124.7 (C-2), 121.8 (C-6a), 107.6 (C-1), $53.2\left(\mathrm{CH}_{3}\right.$ of methoxycarbonyl group from 2 position $), 52.5\left(\mathrm{CH}_{3}\right.$ of methoxycarbonyl group from 1 position), $36.6\left(\mathrm{CH}_{2}\right.$ of bromoacetyl group from 3 position).

Dimethyl 3-(2,2-dibromoacetyl)pyrrolo[2,1-a]phthalazine-1,2-dicarboxylate (15b). 0.077 g, 16\% (under classical heating) and $0.058 \mathrm{~g}, 12 \%$ (under microwaves) as yellowish crystals, m.p. $181-182{ }^{\circ} \mathrm{C} ; R_{\mathrm{f}}$ (99.9/0.1 $\left.\mathrm{CH}_{2} \mathrm{Cl}_{2} / \mathrm{CH}_{3} \mathrm{OH}\right)$ 0.53; IR (cm ${ }^{-1}$ ): 3119, 3032 (C-H arom.), 2951 (C-H aliph.), 1732, 1714 (C=O, ester), 1654 (C=O, keto), 1518, 1498, 1467, 1410, 1392 (aromatic and heteroaromatic ring), 1255, 1236, 1197, 1174, 1114 (C-O-C, ester), 617, 563 (C-Br); ${ }^{1} \mathrm{H}$ NMR $\left(500 \mathrm{MHz}, \mathrm{CDCl}_{3}\right): \delta 9.54(1 \mathrm{H}, \mathrm{d}, \mathrm{J}=8.5 \mathrm{~Hz}$, H-10), 8.79 (1H, s, H-6), 7.93-7.96 (2H, m, H-7, H-9), $7.82(1 \mathrm{H}, \mathrm{dd}, J=7.0,7.5 \mathrm{~Hz}, \mathrm{H}-8), 7.69(1 \mathrm{H}, \mathrm{s}, \mathrm{CH}$ of dibromoacetyl group from 3 position), $4.03\left(3 \mathrm{H}, \mathrm{s}, \mathrm{CH}_{3}\right.$ of methoxycarbonyl group from 1 position), $3.95\left(3 \mathrm{H}, \mathrm{s}, \mathrm{CH}_{3}\right.$ of methoxycarbonyl group from 2 position); ${ }^{13} \mathrm{C} \mathrm{NMR}\left(125 \mathrm{MHz}, \mathrm{CDCl}_{3}\right): \delta 176.8(\mathrm{CO}$ keto group from 3 position), 165.6 (CO keto ester from 2 position), 163.6 (CO keto ester from 1 position), 147.3 (C-6), 134.1 (C-9), 130.7 (C-8), 130.3 (C-3), 129.0 (C-10b), 128.3 (C-7),127.4 (C-10), 126.6 (C-10a), 121.8 (C-6a), 121.2 (C-2), 108.4 (C-1), $53.3\left(\mathrm{CH}_{3}\right.$ of methoxycarbonyl group from 2 position), $52.7\left(\mathrm{CH}_{3}\right.$ of methoxycarbonyl group from 1 position), 43.6 ( $\mathrm{CH}$ of dibromoacetyl group from 3 position).

\section{Conclusions}

In conclusion, we report herein an efficient and straightforward pathway for obtaining a new class of blue fluorescent pyrrolodiazine derivatives under conventional (thermal) heating as well as under unconventional (microwave irradiation) heating. Blue fluorescent pyrrolodiazine derivatives have been obtained using a cycloaddition reaction of pyridazinium/phthalazinium ylides with activated alkynes. Under microwave irradiation, we isolated only fully aromatized cycloadducts with an increased yield (10-15\%). The absorption and emission maxima and corresponding quantum yield of the obtained pyrrolodiazine derivatives were studied, with some of these compounds being moderate blue emitters. The fluorescence quantum yields of pyrrolodiazine derivatives are dramatically dependent on their structure, with only compounds with a pyrrolo-pyridazine skeleton having relative good quantum yields, whereas dihydropyrrolo-phthalazines show negligible and red shifted fluorescence emission.

In order to derivatizate these fluorescent pyrrolodiazines, we performed their bromination in heterogeneous catalysis using copper (II) bromide in chloroform/ethyl acetate. The reactions occur regioselectively both under conventional and unconventional heating to form only $\alpha$-brominated products with increased reactivity. This increased reactivity should allow one to label various macromolecular structures of biological interest with fluorescent pyrrolodiazine moieties.

We also note that under MW irradiation, the reactions occur with increased selectivity regarding monobrominated compounds and offer several advantages in terms of yield, easier workup of the reaction, substantial decrease in consumed solvent and a substantial reduction in reaction time (from hours to minutes, and thus a consequent diminution in energy consumption). Taking into consideration these advantages, the proposed method should be considered environmentally friendly.

Supplementary Materials: Details of the IR spectra and NMR spectra $\left({ }^{1} \mathrm{H}\right.$ NMR and ${ }^{13} \mathrm{C}$ NMR) of the synthesized compounds can be found in the Supporting Information.

Author Contributions: Design, synthesis, and writing were performed by I.I.M., G.Z. and C.M. The evaluation of fluorescent properties was performed by D.M., V.A., D.A.-M., G.Z. and C.M. Experimental work and structure elucidation were performed by V.A., V.M., D.A.-M., G.Z. and C.M. Revision of the first draft of paper, I.I.M., G.Z. and C.M. All authors reviewed and approved the final version.

Funding: This research was funded by UEFISCDI Bucharest, Romania grant number PN-III-P1-1.1-TE-2016-1205.

Acknowledgments: The authors are thankful to UEFISCDI Bucharest, Romania, project PN-III-P1-1.1-TE-2016-1205 for financial support and the POSCCE-O 2.2.1, SMIS-CSNR 13984-901, No. 257/28.09.2010 Project, CERNESIM, for NMR experiments.

Conflicts of Interest: The authors declare no conflict of interest. 


\section{References}

1. Cheng, Y.; Ma, B.; Wudl, F. Synthesis and optical properties of a series of pyrrolopyridazine derivatives: deep blue organic luminophors for electroluminescent devices. J. Mater. Chem. 1999, 9, 2183-2188. [CrossRef]

2. Sandeep, C.; Basavaraj, P.; Venugopala, K.N.; Rashmi, S.K.; Rashmi, V.; Odhav, B. Efficient synthesis and characterization of ethyl 7-acetyl-2-substituted 3-(substitutedbenzoyl) indolizine-1-carboxylates for in vitro anticancer activity. Asian J. Chem. 2016, 28, 1043-1048. [CrossRef]

3. Gundersen, L.L.; Charnock, C.; Negussie, A.H.; Rise, F.; Teklu, S. Synthesis of indolizine derivatives with selective antibacterial activity against Mycobacterium tuberculosis. Eur. J. Pharm. Sci. 2007, 30, $26-35$. [CrossRef]

4. Mantu, D.; Luca, M.C.; Moldoveanu, C.; Zbancioc, G.; Mangalagiu, I.I. Synthesis and antituberculosis activity of some new pyridazine derivatives. Part II. Eur. J. Med. Chem. 2010, 45, 5164-5168. [CrossRef]

5. Zbancioc, A.M.; Zbancioc, G.; Tanase, C.; Miron, A.; Ursu, C.; Mangalagiu, I.I. Design, synthesis and in vitro anticancer activity of a new class of dual DNA intercalators. Lett. Drug Des. Discov. 2010, 7, $644-649$. [CrossRef]

6. Sonnet, P.; Dallemagne, P.; Guillon, J.; Enguehard, C.; Stiebing, S.; Tanguy, J.; Bureau, R.; Rault, S.; Auvray, P.; Moslemi, S.; et al. New aromatase inhibitors. Synthesis and biological activity of aryl-substituted pyrrolizine and indolizine derivatives. Bioorg. Med. Chem. 2000, 8, 945-955. [CrossRef]

7. Narajji, C.; Karvekar, M.D.; Das, A.K. Synthesis and antioxidant activity of 3,3'-diselanediylbis (N, N-disubstituted indolizine-1-carboxamide) and derivatives. S. Afr. J. Chem. 2008, 61, 53-55, ISSN: 0379-4350.

8. Huang, W.; Zuo, T.; Luo, X.; Jin, H.; Liu, Z.; Yang, Z.; Yu, X.; Zhang, L.; Zhang, L. Indolizine derivatives as HIV-1 VIF-ElonginC interaction inhibitors. Chem. Biol. Drug. Des. 2013, 81, 730-741. [CrossRef] [PubMed]

9. Mitsumori, T.; Bendikov, M.; Sedó, J.; Wudl, F. Synthesis and properties of novel highly fluorescent pyrrolopyridazine derivatives. Chem. Mater. 2003, 15, 3759-3768. [CrossRef]

10. Mitsumori, T.; Bendikov, M.; Dautel, O.; Wudl, F.; Shioya, T.; Sato, H.; Sato, Y. Synthesis and properties of highly fluorescent indolizino[3,4,5-ab]isoindoles. J. Am. Chem. Soc. 2004, 126, 16793-16803. [CrossRef] [PubMed]

11. Mitsumori, T.; Craig, I.M.; Martini, I.B.; Schwartz, B.J.; Wudl, F. Synthesis and color tuning properties of blue highly fluorescent vinyl polymers containing a pendant pyrrolopyridazine. Macromolecules 2005, 38, 4698-4704. [CrossRef]

12. Li, Z.; Askim, J.R.; Suslick, K.S. The optoelectronic nose: colorimetric and fluorometric sensor arrays. Chem. Rev. 2019, 119, 231-292. [CrossRef] [PubMed]

13. Wu, L.; Qu, X. Cancer biomarker detection: recent achievements and challenges. Chem. Soc. Rev. 2015, 44, 2963-2997. [CrossRef] [PubMed]

14. Queralto, N.; Berliner, A.N.; Goldsmith, B.; Martino, R.; Rhodes, P.; Lim, S.H. Detecting cancer by breath volatile organic compound analysis: a review of array-based sensors. J. Breath Res. 2014, 8, 027112. [CrossRef]

15. Tisler, M. Structure and reactivity correlation of bicyclic $10-\pi$ electron systems with bridgehead nitrogen. Pure Appl. Chem. 1980, 52, 1611-1621. [CrossRef]

16. Maftei, D.; Zbancioc, G.; Humelnicu, I.; Mangalagiu, I. Conformational effects on the lowest excited states of benzoyl-pyrrolopyridazine: insights from PCM time-dependent DFT. J. Phys. Chem. A 2013, 117, 3165-3175. [CrossRef] [PubMed]

17. Rodriquez, M.; Taddei, M. Synthesis of heterocycles via microwave-assisted cycloadditions and cyclocondensations. In Microwave-Assisted Synthesis of Heterocycle; Van der Eycken, E., Kappe, C.O., Eds.; Springer-Verlag: Berlin/Heidelberg, Germany, 2006; pp. 213-266. ISBN 9783540309833.

18. Perreux, L.; Loupy, A. Nonthermal effects of microwaves in organic synthesis. In Microwaves in Organic Synthesis, 2nd ed.; Loupy, A., Ed.; Wiley-VCH: Weinheim, Germany, 2006; pp. 134-218. ISBN 9783527314522.

19. Zbancioc, G.; Mangalagiu, I.I. Pyrrolopyridazine derivatives as blue organic luminophores: synthesis and properties. Part 2. Tetrahedron 2010, 66, 278-282. [CrossRef]

20. Zbancioc, G.; Huhn, T.; Groth, U.; Deleanu, C.; Mangalagiu, I.I. Pyrrolodiazine derivatives as blue organic luminophores: Synthesis and properties. Part 3. Tetrahedron 2010, 66, 4298-4306. [CrossRef]

21. Zbancioc, G.; Caprosu, M.; Moldoveanu, C.; Mangalagiu, I.I. Microwave assisted synthesis for dimers via [3 + 3] dipolar cycloadditions. Arkivoc 2005, 5, 174-187. 
22. Zbancioc, G.; Bejan, V.; Risca, M.; Moldoveanu, C.; Mangalagiu, I.I. Microwave assisted reactions of new azaheterocyles compounds. Molecules 2009, 14, 403-411. [CrossRef]

23. Zbancioc, G.; Moldoveanu, C.; Zbancioc, A.M.; Mangalagiu, I.I. Microwave assisted synthesis of new pyrrolopyridazine derivatives with acetophenone skeleton. Part V. Curr. Microw. Chem. 2014, 1, 41-46. [CrossRef]

24. Moldoveanu, C.; Mangalagiu, I.; Isac, D.L.; Airinei, A.; Zbancioc, G. A new pathway for the synthesis of a new class of blue fluorescent benzofuran derivatives. Molecules 2018, 23, 1968. [CrossRef] [PubMed]

25. Al Matarneh, C.M.; Apostu, M.O.; Mangalagiu, I.I.; Danac, R. Reactions of ethyl cyanoformate with cycloimmonium salts: A direct pathway to fused or substituted azaheterocycles. Tetrahedron 2016, 72, 4230-4238. [CrossRef]

26. Masaki, Y.; Otsuka, H.; Nakayama, Y.; Hioki, M. Studies on indolizines and azaindolizines. I. The 1,3-dipolar cycloaddition of acetylenic compounds to pyridazinium ylides. Chem. Pharm. Bull. 1973, 21, 2780-2783. [CrossRef]

27. Caira, M.R.; Georgescu, E.; Georgescu, F.; Albota, F.; Dumitrascu, F. Contributions to syntheses of pyrrolo[2,1-a]phthalazines. Monatsh. Chem. 2011, 142, 743-748. [CrossRef]

28. Popa, M.M.; Barbu, L.; Draghici, C.; Dumitrascu, F. 3-Acetyl-pyrrolo[2,1-a]phthalazines by one-pot reaction. U.P.B. Sci. Bull. Series B 2011, 73, 109-114.

29. Zbancioc, G.; Zbancioc, A.M.; Mangalagiu, I.I. Ultrasound and microwave assisted synthesis of dihydroxyacetophenone derivatives with or without 1, 2-diazine skeleton. Ultrason. Sonochem. 2014, 21, 802-811. [CrossRef]

Sample Availability: Samples of the compounds are not available from the authors.

(C) 2019 by the authors. Licensee MDPI, Basel, Switzerland. This article is an open access article distributed under the terms and conditions of the Creative Commons Attribution (CC BY) license (http://creativecommons.org/licenses/by/4.0/). 